\title{
Relationship between Oral Function and Respiratory Disturbance Index in Obstructive Sleep Apnea Syndrome Patients
}

\author{
Hiroyuki Nakano ${ }^{1 *}$, Sho Mizobuchi ${ }^{1}$, Yasuhisa Sawai ${ }^{1}$, Eri Komori ${ }^{1}$, Kei Suzuki ${ }^{1}$, Mayumi Matsumura ${ }^{1}$, Yasuyuki \\ Sasai $^{1}$, Toshiyuki Konda ${ }^{1}$, Soichiro Ikeda ${ }^{2}$, Yoichiro Nakajima ${ }^{1}$, Tomohiro Yamada ${ }^{3}$ and Takaaki Ueno ${ }^{1}$ \\ ${ }^{1}$ Department of Oral Surgery, Osaka Medical College, Japan \\ ${ }^{2}$ Division of Internal Medicine (I), Faculty of Medicine, Osaka Medical College, Japan \\ ${ }^{3}$ Section of Oral and Maxillofacial Surgery, Division of Maxillofacial Diagnostic and Surgical Sciences, Faculty of Dental Science, Kyushu University, \\ Japan
}

Submission: April 08, 2021; Published: May 17, 2021

*Corresponding author: Hiroyuki Nakano, Department of Oral Surgery, Osaka Medical College, 2-7 Daigaku-machi, Takatsuki City, Japan

Abstract

To investigate the relationship between oral function and respiratory disturbance index (RDI). This has not been reported previously. Sixtyone patients (41 males, 20 females) who were treated for obstructive sleep apnea with an oral appliance were enrolled in this study. Mean age and body mass index were $55.5 \pm 12.7$ years and $24.4 \pm 4.0 \mathrm{~kg} / \mathrm{m} 2$, respectively. Patients were classified into groups based on body mass index (non-obese group, $<25.0 \mathrm{~kg} / \mathrm{m} 2$ and obese group, $\geqq 25.0 \mathrm{~kg} / \mathrm{m} 2$ ) and severity of RDI (mild group, $5 \leq \mathrm{RDI}<15$ and moderate and severe group, $\mathrm{RDI} \geq 15$ ). RDI was measured by in-home (portable) monitoring and oral function was measured as maximum occlusal force, tongue pressure and labial closure force. A significant negative correlation was found between labial closure force and RDI in the total cohort and in non-obese cases $(\mathrm{P}<0.05)$. This study suggests that labial closure force may affect sleep-disordered breathing, supporting past reports. Evaluation of labial closure force thus appears very important before treating OSA.

Keywords: Respiratory disturbance index; In-home (portable) monitoring; Maximum occlusal force; Tongue pressure; Labial closure force

Abbreviations: SBD: Sleep-Disordered Breathing; OSA: Obstructive Sleep Apnea; CSA: Central Sleep Apnea; CSR: Cheyne-Stokes Respiration; RDI Respiratory Disturbance Index

\section{Introduction}

The oral cavity, along with the nasal cavity, is one of the entrances for breathing. Many anatomical features of the oral cavity can contribute to sleep-disordered breathing (SDB). Within SDB, several subtypes of sleep disturbance have been identified, including obstructive sleep apnea (OSA), central sleep apnea (CSA) and Cheyne-Stokes respiration (CSR). OSA occurs when obstruction of the upper airway causes cessation of airflow during continued inspiratory effort and is more prevalent among heart failure patients than among the general population [1]. Research comparing the pharyngeal and maxillofacial morphology between patients with and without OSA has identified mandibular retraction, small mandible, low hyoid bone, long face, short cranial base, and long soft palate and pharynx [2,3]. However, evaluating the functions of the jaw, tongue and soft palate has been difficult. In recent years, advances in devices has enabled evaluation of oral functions such as maximum occlusal force, tongue pressure, and lip closure force. However, no reports appear to have investigated the relationship between oral function and respiratory disturbance index (RDI). This study therefore examined the relationship between oral function and RDI.

\section{Materials and Methods}

\section{Patients}

Sixty-one patients ( 41 men, 20 women) who were treated with an oral appliance at Osaka Medical College Hospital from August 2018 to August 2020 were enrolled in this study. Mean age was $55.5 \pm 12.7$ years and mean body mass index was $24.4 \pm 4.0 \mathrm{~kg} /$ $\mathrm{m}^{2}$. Patients were classified into two group based on the severity of RDI, the body mass index: non- obesity group $\left(<25.0 \mathrm{~kg} / \mathrm{m}^{2}\right)$ and obesity group $\left(\geqq 25.0 \mathrm{~kg} / \mathrm{m}^{2}\right)$, mild cases $(5 \leq \mathrm{RDI}<15)$ and moderate and severe cases ( $\mathrm{RDI} \geq 15$ ). 


\section{RDI}

RDI was measured by in-home (portable) monitoring (SAS2100; Teijin Medical Pharma, Tokyo, Japan) of respiration and oxygenation. RDI was defined as the total sum of apnea and hypopnea episodes divided by total sleep time.

\section{Oral functions}

Maximum occlusal force was measured once for each side using a simple occlusal force-measuring device (Occlusal Force Meter GM10; Nagano Keiki Co., Tokyo, Japan) to find maximum values for each subject. Tongue pressure was measured using a tongue pressure-measuring device (JMS tongue pressure measurement device; Morita Corporation, Tokyo, Japan). Labial closure force was measured using a labial closure device (LDC110R Lip De Cum lip force measurement device, Ducklings; Cosmo Instruments Co., Tokyo, Japan).

\section{Statistical analysis}

We conducted statistical analyses with Spearman's rankorder correlation coefficient to evaluate the associations between indicators of RDI and oral function. Correlation coefficients for maximum occlusal force, tongue pressure, labial closure device and RDI were calculated. The level of significance was set as $\mathrm{p}<0.05$.

\section{Ethical considerations}

This study was approved by the ethics committee at Osaka Medical College (approval number 2695) and conformed with the accepted ethical standards formulated in the Declaration of Helsinki 1964 (as revised in 2000). All participants provided informed consent for measurement of oral functions and RDI.

\section{Results}

\section{RDI}

Mean RDI for the total cohort was $20.6 \pm 10.5$ times/h. Among the 18 mild cases (29.5\%), mean RDI was 9.8 \pm 3.5 times/h. Among the 43 moderate and severe cases (70.5\%), mean RDI was $25.2 \pm 9.0$ times/h. Among the 36 non-obese cases (59.0\%), mean RDI was $20.4 \pm 10.3$ times/h. Among the 25 obese cases $(41.0 \%)$, mean RDI was $20.9 \pm 10.7$ times/h.

\section{Oral functions}

Mean maximum bite force was $922.8 \pm 620.9 \mathrm{~N}$ for the total cohort, $1101.9 \pm 642.9 \mathrm{~N}$ in mild cases and $847.8 \pm 595.7 \mathrm{~N}$ in moderate and severe cases. Mean maximum bite force was $935.5 \pm 617.9 \mathrm{~N}$ in non-obese cases and $904.5 \pm 624.8 \mathrm{~N}$ in obese cases. Mean tongue pressure was $30.0 \pm 9.1 \mathrm{kPa}$ for the total cohort, $31.6 \pm 8.6 \mathrm{kPa}$ in mild cases, and $29.4 \pm 9.3 \mathrm{kPa}$ in moderate and severe cases. Mean tongue pressure was $28.8 \pm 9.2 \mathrm{kPa}$ in nonobese cases and $31.8 \pm 8.7 \mathrm{kPa}$ in obese cases. Mean labial closure force was $12.3 \pm 4.2 \mathrm{~N}$ in the total cohort, $13.8 \pm 2.9 \mathrm{~N}$ in mild cases and $11.6 \pm 4.5 \mathrm{~N}$ in moderate and severe cases. Mean labial closure force was $11.7 \pm 4.4 \mathrm{~N}$ in non-obese cases and $13.1 \pm 3$.8N in obese cases (Table 1-3).

Table 1: Total subjects.

\begin{tabular}{|c|c|}
\hline & Total Subjects (n=61) \\
\hline Maximum bite force (N) & $922.8 \pm 620.9$ \\
\hline Tongue pressure $(\mathrm{kPa})$ & $30.0 \pm 9.1$ \\
\hline Labial closure force $(\mathrm{N})$ & $12.3 \pm 4.2$ \\
\hline
\end{tabular}

Table 2: Mild case group and moderate and severe case group.

\begin{tabular}{|c|c|c|c|}
\hline & Mild & $\begin{array}{c}\text { Moderate and } \\
\text { Severe }\end{array}$ & P value \\
\hline $\begin{array}{c}\text { Maximum bite } \\
\text { force (N) }\end{array}$ & $1101.9 \pm 642.9$ & $847.8 \pm 595.7$ & n.s \\
\hline $\begin{array}{c}\text { Tongue pressure } \\
(\mathrm{kPa})\end{array}$ & $31.6 \pm 8.6$ & $29.4 \pm 9.3$ & n.s \\
\hline $\begin{array}{c}\text { Labial closure } \\
\text { force (N) }\end{array}$ & $13.8 \pm 2.9$ & $11.6 \pm 4.5$ & $<0.05$ \\
\hline
\end{tabular}

Table 3: Non-obese and obese case groups.

\begin{tabular}{|c|c|c|c|}
\hline & Non-obese & Obese & P value \\
\hline $\begin{array}{c}\text { Maximum bite force } \\
(\mathrm{N})\end{array}$ & $935.5 \pm 617.9$ & $904.5 \pm 624.8$ & n.s \\
\hline $\begin{array}{c}\text { Tongue pressure } \\
(\mathrm{kPa})\end{array}$ & $28.8 \pm 9.2$ & $31.8 \pm 8.7$ & n.s \\
\hline $\begin{array}{c}\text { Labial closure force } \\
(\mathrm{N})\end{array}$ & $11.7 \pm 4.4$ & $13.1 \pm 3.8$ & n.s \\
\hline
\end{tabular}

\section{Correlations}

A significant negative correlation was found between labial closure force and RDI in the total cohort. (Spearman's rank correlation coefficient: $r s=-0.30: p<0.05$ ) (Figure 1). No correlations were found with other factors, with the exception of a correlation between labial closure force and RDI in the total cohort. A significant negative correlation was found between labial closure force and RDI in non-obese cases (Spearman's rank correlation coefficient: $r s=-0.362$ : $p<0.05$ ) (Figure 2). 


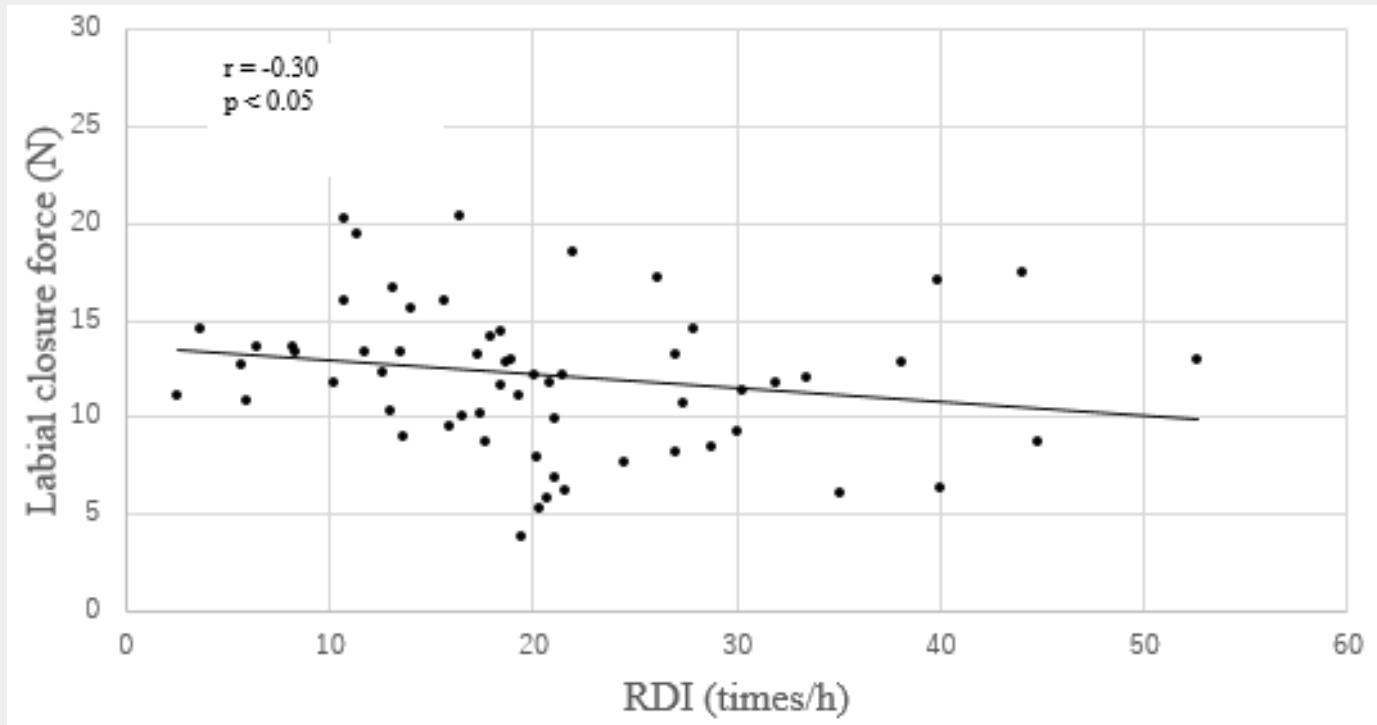

Figure 1: Correlation between labial closure force and RDI in total subjects.

A significant negative correlation was found between labial closure force and RDI in total subjects (Spearman's rank correlation coefficient; rs=-0.30, $p<0.05$ ).

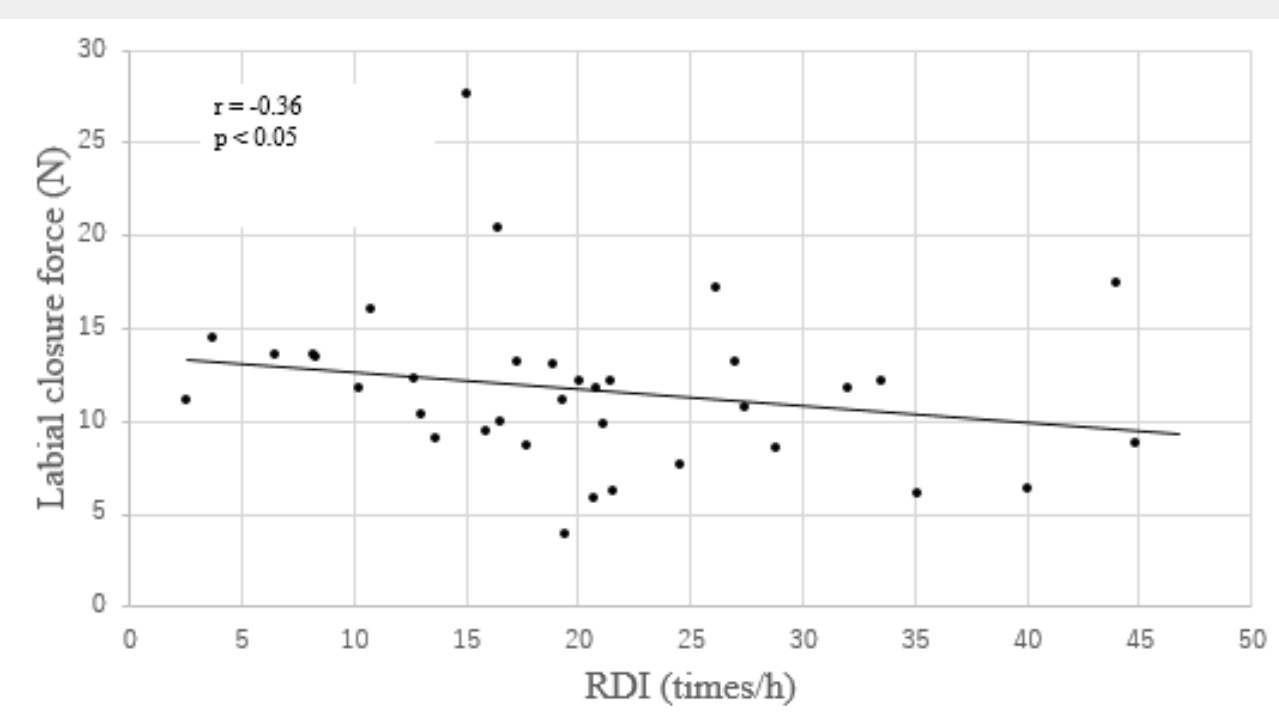

Figure 2: Correlation between labial closure force and RDI in non-obese cases.

A significant negative correlation was found between labial closure force and RDI in non-obese cases (Spearman's rank correlation coefficient; $r s=-0.362, p<0.05)$.

\section{Discussion}

The prevalence of sleep apnea syndrome (SAS) in the global middle-aged work force is reportedly $4 \%$ of men and $2 \%$ of women [4]. Of these, OSA is the most common cause of secondary hypertension [5] and arteriosclerosis, which exacerbates the pathologies of diabetes and dyslipidemia. The causes of OSA can be divided into functional and morphological factors $[6,7]$. As functional factors, hypotonia of the muscles of upper airway dilatation weakens as the upper airway relaxes with the onset of sleep, and the upper airway becomes more susceptible to pressure fluctuations, resulting in narrowing of the airway. In particular, the soft palate and tongue base sink posteriorly, narrowing the pharyngeal cavity in the supine position. In the absence of structural or functional abnormalities in the upper airway, this degree of physiological upper airway stenosis maintains the necessary ventilation during sleep with resting breathing power, resulting in sleep or occasional mild snoring.

However, when a morphologically narrowed upper respiratory tract is added to this, resting breathing during sleep interferes with the required amount of ventilation, resulting 
in OSA consisting of persistent snoring and hyperventilation with apnea and snoring. So far, many reports have examined the morphological characteristics of OSA patients [2,3], but few reports have examined functional factors. In recent years, the advancement of devices has allowed evaluation of oral functions such as maximum occlusal force, tongue pressure, and lip closure force. As a result, many reports have been made on the effects of oral function on the whole body [8-10]. The tongue can be easily considered to have a significant impact on OSA. We suspected that a correlation exists between tongue pressure and Apnea Hyponea Index. However, only the non-obese group showed a correlation between labial closure force and AHI in this study.

We think that the factors that affect AHI in terms of lip closure force are that mouth opening shortens the space between the mandible and the hyoid bone, and that the hyoid bone retracts, causing the tongue to rise and fall into the pharyngeal cavity. When narrowing occurs to the extent that the nasopharyngeal cavity downstream of the airway is affected by turbulence, airway resistance is increased [11]. When nasal cavity resistance is further increased, Bernoulli's principle causes the nasal cavity to become a resistance tube, and a strong negative pressure is generated in the pharynx below the nasal cavity, pulling in the soft palate, as the softest tissue in the region. Airway narrowing can thus result [12]. Takamoto et al. [13] reported on training methods and devices to increase labial closure force. Moreover, they reported that labial closure force training ameliorated eating dysfunction, decreased daytime sleepiness, and activated the prefrontal cortex in elderly individuals. That report supports our results. In patients with OSA, measuring labial closure force before treatment may be important when choosing a treatment method.

\section{Conclusion}

This study suggests that labial closure force may affect SDB, supporting previous findings. Evaluating labial closure force appears very important before treating OSA.

\section{References}

1. Oldenburg O, Lamp B, Faber L, Teschler H, Horstkotte D, et al. (2007) Sleep-disordered breathing in patients with symptomatic heart failure: a contemporary study of prevalence in and characteristics of 700 patients. Eur J Heart Fail 9(3): 251-257.
2. Kikuchi M, Higurashi N, Miyazaki S, Itasaka Y (2000) Facial patterns of obstructive sleep apnea patients using Ricketts method. Psychiatry Clin Neurosci 54(3): 336-337.

3. Lowe AA, Ozbek MM, Miyamoto K, Pae EK, Fleetham JA (1997) Cephalometric and demographic characteristics of obstructive sleep apnea: an evaluation with partial least square analysis. Angle Orthod 67(2): 143-154.

4. Young T, Palta M, Dempsey J, Skatrud J, Weber S, et al. (1993) The occurrence of sleep-disordered breathing among middle-aged adults. N Engl J Med 328(17): 1230-1235.

5. Nieto FJ, Young TB, Lind BK, Shahar E, Samet JM, et al. (2000) Association of sleep disordered breathing, sleep apnea, and hypertension in a large community-based study. Sleep Heart Health Study. JAMA 283(14): 1829-1836.

6. Punjabi NM, Ahmed MM, Polotsky VY, Beamer BA, O Donnell CP (2000) Sleep-disordered breathing, glucose intolerance, and insulin resistance. Am J Epidemiol 160(6): 521-130.

7. Robinson GV, Pepperell JC, Segal HC, Davies RJO, Stradling JR (2004) Circulating cardiovascular risk factor in obstructive sleep apnea: data from randomized controlled trials. Thorax 59(9): 777-782.

8. Suzuki K, Kato Kogoe N, Inoue K, Omori M, Imagawa N, et al. (2020) The relationship between jaw function and cognitive function in the elderly population. Journal of Hard Tissue Biology 29(3): 169-172.

9. Imagawa N, Kato Kogoe N, Suzuki K, Omori M, Suwa Y, et al. (2020) Relationship between oral function and occlusal bite force in the elderly. Journal of Hard Tissue Biology 29(3): 165-168.

10. Suzuki K, Nakano H, Kato Kogoe N, Inoue K, Omori M, et al. (2020) A preliminary study of the relationship between oral and vascular function in the elderly population. Journal of Hard Tissue Biology 29(3): 161-164.

11. Lee SH, Choi JH, Shin C, Lee HM, Kwon SY, et al. (2007) How does openmouth breathing influence upper airway? Laryngoscope 117(6): 11021106.

12. Nishimura T, Suzuki K (2003) Anatomy of oral respiration: morphology of the oral cavity and pharynx. Acta Otolaryngol Suppl 550: 25-28.

13. Takamoto K, Saitoh T, Taguchi T, Nishimaru H, Urakawa S, et al. (2018) Lip closure training improves eating behaviors and prefrontal cortical hemodynamic activity and decreases daytime sleep in elderly persons. J Bodyw Mov Ther 22(3): 810-816. 
This work is licensed under Creative Commons Attribution 4.0 License DOI: 10.19080/ADOH.2021.14.555883
Your next submission with Juniper Publishers will reach you the below assets

- Quality Editorial service

- Swift Peer Review

- Reprints availability

- E-prints Service

- Manuscript Podcast for convenient understanding

- Global attainment for your research

- Manuscript accessibility in different formats

( Pdf, E-pub, Full Text, Audio)

- Unceasing customer service

Track the below URL for one-step submission https://juniperpublishers.com/online-submission.php 